\title{
Aspects of Marketing in Dental Tourism-Factor of Sustainable Development in Romania
}

\author{
Flavia Dana Oltean ${ }^{1}$, Manuela Rozalia Gabor ${ }^{1, * \mathbb{C}}$, Aurélia-Felicia Stăncioiu ${ }^{2}$, Mihaela Kardos ${ }^{1}$, \\ Marta Kiss ${ }^{1}$ and Roxana Cristina Marinescu ${ }^{3}$ \\ 1 Economic Sciences Department, “George Emil Palade” University of Medicine, Pharmacy, Sciences and \\ Technology of TârguMureș, Faculty of Economics and Law, 540139 TîrguMureș, Romania; \\ flavia.oltean@umfst.ro (F.D.O.); mihaela.kardos@umfst.ro (M.K.); marta.kiss@umfst.ro (M.K.) \\ 2 Faculty of Marketing, Bucharest University of Economic Studies, 010374 Bucharest, Romania; \\ stancioiufelicia@hotmail.com \\ 3 Faculty of Economics and Business Administration, University of Craiova, 200585 Craiova, Romania; \\ roxanaseverineanu@yahoo.com \\ * Correspondence: manuela.gabor@umfst.ro or rozalia_gabor@yahoo.com
}

Received: 25 April 2020; Accepted: 20 May 2020; Published: 25 May 2020

\begin{abstract}
Dental tourism is a growing and emerging phenomenon that is becoming more attractive to patients due to its potential for decreased expenses, increased convenience, and immediacy of treatment. The necessity for travel is the primary motivation for seeking dental treatment due to the successful cooperation between tourism and healthcare. While dental tourism has been largely researched from the perspective of the patient, our research is the first research to apply a concomitant approach on dental clinics and tourism agencies. The aim of our study wasto provide comprehensive empirical evidence from the perspective of the dental clinics and tourism agencies in Romanian dental tourism. We used a representative sampling with an online questionnaire on 160 dental clinics and 32 tourism agencies. The results indicate that both entities have small amounts of information, but they are interested in investing, promoting, and creating a partnership to create a sustainable industry of dental tourism. Dental tourism could strongly contribute to the country's image and help to prolong the seasonality of tourism activity by enhancing the strategic marketing of dental clinics and tourism agencies toward sustainable health tourism.
\end{abstract}

Keywords: medical tourism; dental tourism; Romania; dental clinics; tourism agencies; sustainable tourism; marketing

\section{Introduction}

Medical tourism is a term that describes seeking medical treatment in another country [1], and it is defined [2] as the process of leaving home for treatments and care abroad or elsewhere domestically.

Medical tourism is a relatively new phenomenon [3] and it is considered to be the most important component of trade in health services [4,5]. Many studies, at a national and international level, have investigated the link between medical tourism and sustainability, mostly concluding that in certain conditions, medical tourism contributes to the destination countries' economic growth and jobs creation, leading to sustainability opportunities [6]. Medical tourism is a peculiar tourism phenomenon that took on a global characteristic due to the increase of tourists' mobility [7], the economic implications [8], the economic changes that are beneficial in some developing countries [9], and the potentially significant implications for global public health [10]. Such countries as India [11,12], Hungary [13,14] Turkey [15], South Korea, Mexico, and Costa Rica are now at the top of the medical tourism industry $[2,9,13,16]$ and have high percentages of travel receipts relative to GDP [17], mostly because of the capability 
of increasing patient satisfaction, recognized as a core tool for measuring the performance of the hospitals as well as the service provider and the services that they providing to the patients $[5,18]$. For example, in 2016, Croatia had travel receipts of 18.6\% relative to GDP, Albania 14.2\%, Bulgaria 6.8\%, Hungary $4.5 \%$, and Poland $2.3 \%$, whileRomania had travel receipts of only $0.9 \%$ relative to GDP with a negative balance of payments.

Travel overseas for dental treatment is said to be the most prevalent form of medical tourism [19]. Dental tourism is a growing [20-24] and emerging [2] phenomenon that is becoming more attractive to a number of patients due to the decreased expenses, increased convenience, and immediacy of treatment [1,25]. Dental tourism is driven by numerous factors [7], such as the following: high costs of local care, delay in obtaining access to local dentists, many international clinics, and inexpensive air travel. In healthcare, the value proposition in a consumer transaction usually involves considerations of price, quality [26-28], and service [2,29]. For example, Austrians and Italians travel to Slovenia to obtain the best value for their money [30]. The quality of the healthcare delivery system in developed nations has had a significant impact on developing countries [18] or emerging economies. According to the international literature recommendations, dental tourism needs to be further investigated from various aspects and in different environments [31] and, in our opinion, especially with respect to the sustainable destinations. Therefore, we propose a new approach, from the perspective of an excommunist country with an increasing potential to develop sustainable destination, with concomitant research (tourism agencies and dental clinics).

While the international literature mentions many motivations and factors for medical and/or dental tourism $[7,19,22,28,32-34]$, we agree that the necessity for travel may be the sole or primary motivation for seeking medical or dental treatment $[1,32]$ due to the successful cooperation between the tourism and healthcare sectors [35]. Currently, consumers are willing to travel to obtain care that is both safe and less costly [2]. It may also create many memories and experiences [35], since dental tourism is mostly a personal experience [36,37]. In fact, health tourism is not a phenomenon of countries that have poor healthcare but is a phenomenon of choice [38].

The rapid development of these types of tourism is due of the internet, and especially internet advertising [1,12,39-42], since the internet has the capacity to link "customers" to "sellers" of healthcare related services $[7,19,43]$. Patient satisfaction has been observed as a vital concept in the sector of services [5,18], including the dental care services. Dental care information access is one of the important motivational factors for dental tourism [18,32]. Additionally, the rising costs of dental care and consumerism in developed countries have important roles in decisions to purchase dental care abroad [43], but the subjective perception of the costs must be considered [37]. The healthcare sector consider patient satisfaction as the main element of improvement and quality of service delivery systems [18].

In the studied literature, we found another important aspect of dental tourism worldwide: an important percent of dental tourists are migrants. In other words, $17 \%$ of immigrants (respectively, Latino immigrants) from the USA received medical care in a foreign country (Jang, 2017), and the same situation was observed in Albania [38]. In Romania, approximately $70 \%$ of foreign tourists are Romanians living abroad who return to the country for dental care or other healthcare services [44]. In Poland, female migrants in Europe travel to their country of origin for the personal comfort derived from linguistic and cultural competency [45], and cultural affinity and familiarity are two of the main drivers for dental tourism [37,39]. Additionally, Jaapar et al. [32] mentioned two types of dental tourists: the classical and the migrant. A fraction of immigrants decide to travel abroad because they want to return home to their countries of origin and receive care within a health care system with which they are familiar [46]. Starting with the general and well-known definition of a medical tourist [47], Zoltan and Maggy [48] highlighted that is not a useful definition because it mixes dental migrants (or commuters) with dental tourists in a strict sense.

According to the site Patients Beyond Borders [49], former eastern European communist countries, such as Hungary [50], are among the top destinations recommended by these specialists; therefore, 
we consider the possibility of Romania "joining" this growing market [9]. Countries from central and eastern Europe have much to offer with respect to medical procedures, medical equipments, qualified staff, and modern technology [35], and they can advertise low-cost dental treatments [50]. Medical equipment plays an essential role in healthcare services (including dental care services) and is associated with patient satisfaction [18]. With a high growth rate for northeastern and southeastern Europe [49], the Romanian dental tourism market has a strong growth potential based on attractive prices [51] and is one of the most popular destinations for dental tourism in Europe [31,52]. According to UNWTO [53], the countries that joined the EU in 2004 and 2007 have the potential to become new motors for European tourism in the role of being sustainable destinations for the region. Sustainable development of the dental tourism industry, as well as any form of tourism, must consider both medical tourists and local communities, aiming to provide them enhanced development opportunities for the present and future [54].

According to the literature review, we present-comparatively-in Table 1, the advantages and the disadvantages for travelers both within Europe and/or worldwide.

Table 1. The advantages and the disadvantages of dental tourism.

Advantages Disadvantages

- For Europeans to travel for dental care in central and eastern European countries, the advantage is that there are not large cultural differences [35]. For example, UK citizens are the most active dental tourists in Europe and are followed by the Germans, Austrians, and Irish [50].

- Additionally, in order to develop dental tourism in Romania, we must consider that $75 \%$ of Europeans do not travel outside of the European Union and 3-20\% of Europeans receive treatment in another EU country [38].

- Health holidays represent $15 \%$ of the total European international holiday market [55-59], and dental tourism is more regional than global.
- Accountability, differences in training, and the risk of indentions [1];

- Dental tourism could be below the developed/industrial standard of care and the patients may come back to their home country for certain postoperative procedures $[20,21]$;

- Dental tourism has profound impacts upon the provision of dental health in the generating region [19] and the possible growth in health system inequities [22];

- Dental tourism raises many ethical issues $[25,59]$, especially regarding the dentist-patient relationship [21].

The perils of dental vacations include the following:

- $\quad$ Possible anesthetic and methodological consequences [60];

- $\quad$ Possible complications for patients [19];

- $\quad$ Risks facing medical tourists [7].

Some authors from developed countries signal the need to educate their patients and to be a well-informed patient [20]; in our opinion (based on the abovementioned disadvantages), in developed countries, it is necessary to redefine the whole health system (not only the patients), and the development of medical and dental tourism globally must be a signal for them. Actual medical tourism is challenging our traditional ways of thinking about public health [12].

Romanian medical and dental tourism show certain particularities that are emphasized in the published national and international research literature, among them:

- Dental tourism represents a rather new concept in specialty national studies [9];

- The 1997 Romanian government policy [61] supported the dental sector by privatizing public dental clinics;

- Romanian dental clinics cover all types of dental services, including dental surgery [51];

- Romanian dentists are good English speakers [52];

- Romania has a dedicated web page for dental tourism in six international languages; 
- Regarding international standards and ethical issues, Romania, due to being a EU member, respects and applies the EU directives $[19,23,35,50]$;

- Romania was found to provide the best dental services at the lowest costs over a relatively shorter period of time [62].

To have an overall image of the Romanian health system, in Table 2, we present a comparison of the physicians' and dentists' densities per 1000 population for several important dental destinations and Romania according to the WHO (latest data available).

Table 2. Physicians' and dentists' densities (per 1000 population) according to the WHO.

\begin{tabular}{ccccccc}
\hline Year & India & Hungary & Bulgaria & Croatia & Poland & Romania \\
\hline \multicolumn{7}{c}{ Physicians' } \\
\hline 2013 & - & 3.199 & 3.984 & 3.021 & 2.207 & 2.669 \\
2014 & 0.725 & 3.316 & 3.999 & 3.126 & 2.271 & - \\
2015 & 0.758 & 3.093 & - & - & 2.290 & - \\
\hline \multicolumn{7}{c}{ Dentists' Density (Per 1000 Population) } \\
\hline 2013 & - & 0.601 & 1.006 & 0.755 & 0.319 & 0.72 \\
2014 & 0.119 & 0.627 & 0.98 & 0.782 & 0.339 & - \\
2015 & - & 0.602 & - & 0.852 & 0.326 & - \\
2016 & 0.149 & - & - & - & - & - \\
\hline
\end{tabular}

(Source: [49]).

According to the data from Table 2, we can conclude that the low numbers of physicians and dentists in India do not affect the success of dental tourism for this country. Additionally, compared with other European countries that are known to be successful destinations for dental tourism, Romania has a good density for physicians and dentists per 1000 population. Nevertheless, according to Kovacs et al. [13], the statistical data are available only for publicly funded dental services, and private practices are invisible to health policy.

In Table 3, we present the statistical data for Romania and the Center Development Region regarding the number of dentists, the number of tourism agencies, and the tourist arrivals over the most recent years.

Table 3. Number of dentists and tourism agencies in Romania and the Center Development Region.

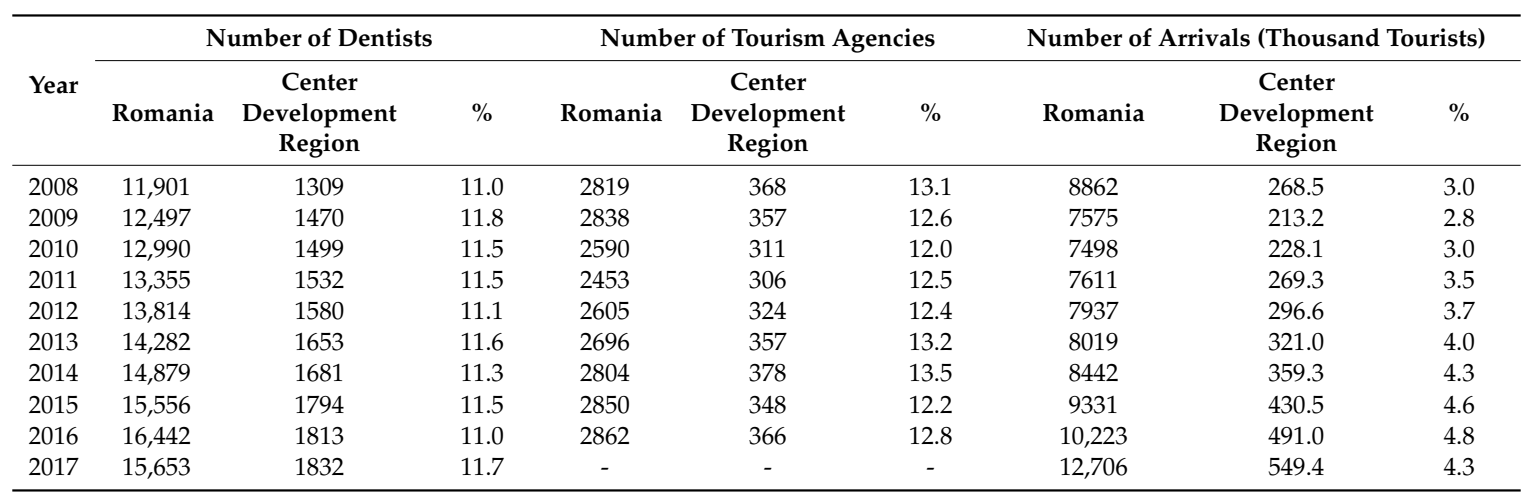

From the data of Table 3, we can observe that both the numbers of dentists and tourism agencies have followed an approximately constant evolution over the last 10 years with a little decrease in the number of tourism agencies for the period 2010-2012, which corresponds to the economic crisis in Romania. Additionally, with respect to the number of dentists at the national level for the last 10 years, the average change was 31.5\%, and for the Center Development Region, it was 39.4\%. With respect to the number of tourism agencies, the average change was approximately the same at $\cong 1 \%$ for Romania and the Center Development Region. 
According to the statistical data from the Tables 2 and 3, the increases in the numbers of dental clinics and dentists could be a good premise for the development of dental tourism in Romania, and especially the Center Development Region. Additionally, we chose this region for the study because it is one of the most visited in Romania and because if the destination has no touristic value for the dental tourist, then we cannot usefully consider this as being dental tourism $[38,44]$. Therefore, we considered that Romania has the necessary preconditions and key resources for the sustainable development of the dental tourism development. Regarding the evolution of dentists from 2008-2017, we mention that the number of dentists in the public sector decreased from 4047 in 2008 to 1619 in 2017 for Romania and from 456 to 194 for the Center Development Region. Additionally, over this same time period, the number of dentists in private sector increased from 7834 to 14,034 for Romania and from 853 to 1638 for the Center Development Region. In fact, the number of dentists in the private sector has doubled over the last 10 years. Another important indicator for Romania is that the number of tourists that arrived in Romania increased from 8862 thousands tourists in 2008 to 12,706 thousands tourists in 2017, which is an increase of $43.4 \%$ for this time period. For the Center Development Region, the number of tourist arrivals increased by $104.6 \%$ from 2008 to 2017, and the percentage of tourist arrivals in the Center Region with respect to the national total increased from 3\% in 2008 to $4.3 \%$ in 2017.

The practical aim of our study was to provide, for the first time in literature, the results of research regarding some marketing aspects, not from a patient and tourist point of view but from the perspectives of dental clinics and tourism agencies in Romanian dental tourism. The scientific aim of this study was to contribute to the growing dental tourism research in the emerging markets of new dental tourism destinations by measuring the awareness and interest of both Romanian dental clinics and tourism agencies in the sustainable development of the dental tourism industry using a representative sampling with an online questionnaire.

Therefore, the practical goals of this research were as follows:

- To determine if there is an intention of cooperation between dental clinics and tourism agencies from Romania to promote dental tourism, and therefore to identify specific activities for promoting Romanian dental tourism by testing a set of six hypotheses developed according to literature references.

- To prove that the main motivation for travel of patients is the increase of their satisfaction, from both a dental services and tourism services point of view.

Dental (and medical) tourism has been largely researched from the perspective of the patient [19], and our research is the first research to apply a concomitant approach on dental clinics and tourism agencies in Romania and worldwide. Our motivation for this approach was to prove that the travelling patient aims to purchase a particular medical service but the nonmedical parts (e.g., accommodations, restaurants, and excursions) are also significant to the total experience [35]. Additionally, we have considered the process flow of dental tourism described by Reddy [63], in which a foreign tourist's dental tourism could be addressed by the travel agents or the dentists.

This research has both scientific and practical values, especially for dental clinics, tourism agencies, and tourism destination stakeholders. This study can model the delivery of dental care services to fulfill the international demand more efficiently and according to the international standards and ethical practices.

\section{Materials and Methods}

To fulfill the goal and scope of this research, the data collection procedure was made by two online self-managed questionnaire surveys $[19,35,50]$ with closed thematic questions, which were sent to 183 dental clinics and 37 tourism agencies by means of the Google Docs platform using stratified and quota sampling. The data were gathered from March-May 2019. For the targeted population of the study, we used a quota sampling of $10 \%$ from the total number of dentists and tourism agencies in 
the Center Development Region according to the data from Table 2. After receiving the completed questionnaires, this research included 160 dental clinics and 32 tourism agencies from the Center Development Region, which corresponded approximately to a $10 \%$ quota sampling as a representative sample at the national level. The response rate was $87 \%$ for both dental clinics and tourism agencies.

Based on the literature review, we formulated the following research hypotheses (Table 4).

Table 4. The research hypotheses.

\begin{tabular}{|c|c|}
\hline Hypothesis & Literature Review for Each Hypothesis \\
\hline $\begin{array}{l}\text { H1-The doctor-patient communication is mainly based on } \\
\text { patients' recommendations in Romania. }\end{array}$ & {$[7,14,26,32,34,35,39,64]$} \\
\hline $\begin{array}{l}\text { H2-Romanian dental clinics predominantly use the internet } \\
\text { to advertise procedures to national and international patients } \\
\text { by their own internet page and/or social media, in } \\
\text { international languages and Romanianlanguage for the } \\
\text { Romanian emigrants. }\end{array}$ & {$[7,32,36,39]$} \\
\hline $\begin{array}{l}\text { H3-A small number of market-oriented strategies are used } \\
\text { to promote dental tourism. }\end{array}$ & {$[28,49]$} \\
\hline $\begin{array}{l}\text { H4-Dental clinics and tourism agencies have the intention } \\
\text { to invest in marketing activities. }\end{array}$ & {$[50]$} \\
\hline $\begin{array}{l}\text { H5-There is a low level of online information regarding } \\
\text { dental tourism services in the Romanian dental clinics (price, } \\
\text { time of services, etc.) and dedicated dental tourism packages } \\
\text { in the tourism agencies. }\end{array}$ & [9] \\
\hline $\begin{array}{l}\text { H6-The Romanian dental clinics offer a competitive, wide } \\
\text { range of dental services. }\end{array}$ & {$[46,47]$} \\
\hline
\end{tabular}

Source: Made by the authors.

The types of questions used in the questionnaire inlcuded multiple choice and a 5-point Likert scale (1-very interested, 5-not interested) responses. For the data analysis and hypotheses testing, we used descriptive statistics, respectively, the relative frequencies and average scores.

\section{Results}

In Table 5, we present-comparatively for tourism agencies and dental clinics—the average scores for each item measured with a 5-point Likert scale.

Table 5. The average score for items.

\begin{tabular}{llc}
\hline \multirow{1}{*}{ Items } & \multicolumn{2}{c}{ Average Scores } \\
\cline { 2 - 3 } & \multicolumn{1}{c}{ Dental Clinics } & Tourism Agencies \\
\hline 1. How much do you know about dental tourism? & 3.20 & 2.5 \\
2. Would you like to find out more about dental tourism? & 3.95 & 3.6 \\
$\begin{array}{l}\text { 3. Would you be interested in promoting your dental clinic } \\
\text { on a dedicated "dental tourism" web page? }\end{array}$ & 3.7 & 4.3 \\
$\begin{array}{l}\text { 4. Would you be interested in establishing a partnership } \\
\text { with a travel agency or a dental tourism consortium? }\end{array}$ & 3.6 & 3.6 \\
\hline
\end{tabular}

Source: Made by the authors.

For dental clinics, regarding "What promotion methods are you currently using?", the results were as follows: $39 \%$ did not use any method of promotion, $22 \%$ had their own web page, $17 \%$ used other methods (including patient recommendations and word-of-mouth), 13\% used local publications, and $9 \%$ used online advertising in Romania. None used the promotional method of national and international publications. Also, 39\% of dental clinics declared that do not use any form of promotion. We also considered that they were based on patient recommendations (word-of-mouth); therefore, 
$56 \%$ of dental clinics in the study primarily used patient recommendations (word-of-mouth) for promoting their dental services.

A high percentage of dental clinics in the sample (67.5\%) were interested in investing in increasing the dental clinic standards for participating in a dental tourism national program, $20 \%$ were not interested in this, and $12.5 \%$ were neutral with respect to this aspect.

Regarding concrete investments, the following results were shown: 52\%-equipment and materials, 34\%-training programs for dental clinics' human resources, and 5\%-human resources. A total of $9 \%$ indicated that they make all kinds of investment and $0 \%$ indicated that they make no investments in any area of dental clinic activities.

The structure for actual dental services made by the dental clinics from the sample was as follows: prostheses-15\%, dentistry-4\%, prophylaxis-13\%, endodontics-13\%, esthetics dental services-11\%, pedodontics $-10 \%$, periodontology $-7 \%$, oral surgery $-6 \%$, implants $-4 \%$, dental radiology $-4 \%$, and orthodontics- $3 \%$.

Regarding the optimal time for treatment that was estimated by the dental clinics, they indicated an average time of approximately 15 days for a treatment-69\% indicated $10-14$ days, $17 \%$ indicated over 14 days, and $14 \%$ marked 5-10 days.

Regarding the right time for dental tourists, the distribution indicated the following: autumn-32\%, summer-30\%, spring-24\%, and winter- $14 \%$.

For tourism agencies, regarding item 3 from the previous table, $25 \%$ of tourism agencies already had dental tourism packages.

Regarding the concrete investments for the development of a dental tourism program, the distribution indicates that $100 \%$ engaged in advertising, promotions, and direct marketing, $0 \%$ engaged in training or supplementing the existing staff of the tourism agencies, and $0 \%$ engaged in other types of investments. These results demonstrate that Romanian dental clinics are shifting toward a market-oriented strategy and developing efficient programs by adopting patient satisfaction [27].

The distribution for the tourism services offered by the tourism agencies included the following: accommodations-28\%, transport-24\%, tourism programs- $17 \%$, consultancy-14\%, guides in English or another international language $-10 \%$, and guides in Romanian $-7 \%$.

Regarding the right time for dental tourists, the distribution indicated the following: spring - $33 \%$, autumn $-28 \%$, summer- $28 \%$, and winter- $11 \%$.

By comparing the results from Table 5, we concluded that:

- The Romanian tourism agencies from the Center Development Region are much more informed about dental tourism;

- Both tourism agencies and dental clinics consider they need more information about dental tourism;

- Both tourism agencies and dental clinics are interested in expanding their own business;

- Both tourism agencies and dental clinics are interested in establishing a partnership or a dental tourism consortium to promote their packages or dental services.

\section{Discussion}

Regarding H1, our results confirmed it because $56 \%$ of Romanian dental clinics from the study used primary recommendations (word-of-mouth) for promoting their dental services. These results are in line with the results of Hussain et al. $[18,26]$, who found that in the health care system, information services are considered as the key indicators of patient satisfaction and as the backbone of a successful healthcare system [18]. The relationship between physicians and patients involves considerable handling, which has a significant influence on the patient satisfaction level [26,65].

$\mathrm{H} 2$ was partially confirmed, because only $31 \%$ of the Romanian dental clinics from the study had their own web page or used online advertising in Romania.

$\mathrm{H} 3$ and $\mathrm{H} 4$ were also partially confirmed, because only $13 \%$ of dental clinics used local publications for marketing and $25 \%$ of tourism agencies already had dental tourism packages. Nevertheless, when we 
considered the high percentage of dental clinics $(67.5 \%)$ that invested in increasing dental clinics standards and that $100 \%$ of tourism agencies engaged in advertising, promotions, and direct marketing, we concluded that these hypotheses were confirmed.

The role of information sources (history books, geography, biology, literature, etc.), films, guides, atlases, brochures, and catalogs is to substantiate the information-alongside those taken from other sources, such as online travel agencies, online publications, blogs, newsletters, mobile applications, and Facebook pages and applications, which outline that choice of consumption [66]. Patients can face issues regarding the registration services, such as no online appointment system, which negatively affect patients [65].

H5 was confirmed because the low level of the average score (3.2 for dental clinics-Table 2-and 2.5 for tourism agencies-Table 3) indicates a low to neutral level of this kind of information. Nevertheless, both entities want to find out more about dental tourism (3.95 for dental clinics and 3.6 for tourism agencies), want to promote their services on a dedicated "dental tourism" web page (3.7 for dental clinics and 4.3 for tourism agencies), and want to establish a partnership as part of a dental tourism consortium (3.6 for dental clinics and for tourism agencies).

H6-The Romanian dental clinics practice a wide range of dental services-was also confirmed.

Taking into account the present results, referring to the possibility of a partnership between dental clinics and tourism agencies, we recommend following the example of Hungary, where most agencies and clinics have agreements with three-star partner hotels or apartments [50].

We could, also, follow the example of EU governments and companies that are offering cheap flights, have open borders, and offer inclusive packages to develop this segment of the tourism market [67]. The distance and, in our opinion, the free traveling in the EU are important factors that influence patient satisfaction in the healthcare delivery system [18].

At the same time, for both dental clinics and tourism agencies, as per these results, the right time for dental tourism, we can conclude, is not perceived to be seasonal. In fact, the globalization transformed tourism from a seasonal activity into a needs activity [36]. Therefore, we emphasize that dental tourism can reduce seasonality and could have a positive impact on the economy [50] by increasing labor quality in both fields (tourism and healthcare), as well as being sustainable.

This, unequivocally, will lead to meeting the needs of the present without compromising the ability of the future generations to meet their own needs [68].

According to the present results, from the theoretical point of view, out study is the first one made concomitantly from both sides of dental tourism, tourism agencies and dental clinics, having implications for academicians by giving the information from a country with real potential for this type of tourism.

Also, from the practical point of view, this research pointed out practical implications and practical values for dental clinics, tourism agencies, and tourism destination stakeholders. The practical implications were to provide comprehensive empirical evidence from the perspectives of dental clinics and tourism agencies in the Romanian dental tourism industry. The present results are the first step from a complex research project regarding new types of tourism, dental tourism being one of them. By measuring the awareness and interest of both Romanian dental clinics and tourism agencies in the sustainable development of dental tourism using a representative sampling with an online questionnaire, we have constructed the basis for extended research with more complex statistical methods.

\section{Conclusions}

Based on this research, we conclude that Romania could become one of the countries that is a top destination for dental tourism [9] and an efficient marketing initiative [44] will encourage more individuals to travel for dental care [7]. In fact, dental clinics should enhance their strategic marketing to lure international clients [50]. 
The price attractiveness of Romanian dental clinics is complemented by the very high specialization in international standards of the Romanian dentists, by massive investments in new technologies, and by the large number of existing dental clinics in Romania [9].

For promoting Romanian dental tourism, it is not sufficient to have well-qualified human capital and competitive prices. The infrastructure is also important because a well-developed infrastructure increases the attractiveness of the destination when deciding where to go $[8,12,44,61]$ and whether to include dental tourism in the Romanian tourism policy and national strategy [31,40]. The Romanian government hopes to establish a quality management system to gain confidence among foreigners seeking medical treatment in Romania [36] because care should be arranged only in accredited international healthcare facilities [50]. In Hungary, for example, this aspect is mandatory [13]. Establishing high standards should reduce the risk that patients face when they travel abroad for health care [49] and government ministries need to use legislative powers to manage and reduce these risks [49].

Concerning us, the limits of the study are: the limited area for data collection (the Center Development Region of Romania) and the limited number of dental clinics and tourism agencies considered in the study.

In fact, dental tourism, or dental vacations [63], is a niche segment [35] of the medical tourism industry with rapid growth that is still studied globally. Sometimes, it is characterized as yet another example of globalization [7,36] or is favored by the process of globalization [69]. Health tourism could be an opportunity for developing countries, especially Romania, to improve both their economies and national health systems and experience overall growth in commerce and insurance [63]. Romania is becoming one of the more accessible countries for dental tourism. In this sense, Romania could follow the example of Hungary, which has the financial support of the Hungarian government for the development of dental tourism [50,62,70] and has found a good solution to the "brain-drain" trend [14]. Hungarian dentists also use various European Union supports [50]. There are also other developing countries, such as Thailand, Singapore, and India, that were part of government plans [36]. We also recommend that the Romanian government support and evaluate dental tourism development as an economic process and an opportunity for sustainable healthcare tourism [50].

This study was a first step in the complex research made by the authors regarding the marketing aspects for Romanian dental tourism. The results of this research were the basis for a complex statistical analysis using complex methods (i.e., principal component analysis, cluster analysis, regression analysis), with the extension of the actual sample to include tourism agencies and dental clinics from all Romanian development regions.

Medical tourism (and implicitly dental tourism) gives an opportunity for developing countries, especially for those that are leaders in the field, to grow economically [53]. In this context, dental tourism has begun to solidify in Romania because of its competitive prices and the quality of its services [69]. Medical tourism currently generates 60 billion dollars globally and the number of countries offering advanced medical care for foreign tourists is growing [71]. Patients generate relevant tourism revenues for the destination country beyond the direct income of the dental clinics [49].

Such countries as Hungary, India, and Poland can be used by Romanian stakeholders as examples for future organizations in the marketing of this specific type of tourism $[35,39]$. As per our opinion, the main reason why Romania is not among the most visited dental tourism destinations (such as Hungary or Poland) is the passivity of Romanian surgeons [35] and because a small percent of Romanian dental clinics use search engine marketing (SEM) and search engine optimization (SEO) [35]. Thus, if the websites of the dental clinics and tourism agencies do not incorporate SEO, potential clients searching on Google cannot find them. Additionally, to maximize the impact of internet advertising, multilingual online communication is recommended [69]. The decreasing of the waiting time of patients for obtaining dental care services (and to travel abroad for a tourism motivation) and the possibility of online appointments will contribute towards ultimate patient satisfaction [65]. Cohen and Rogers [39] 
recommend the primary marketing piece to be the website, which includes the message, images, and the language that are needed to conform to the culture of the intended marketplace.

Currently, the Romanian tourism market is facing a lack of unity in terms of how tourist attractions correlate to the forms of tourism that should be the basis of brand elements-the success of promotional actions can only take place if specific marketing strategies are created for different segments of consumers that can only be targeted through certain communication channels. In this sense, it is necessary to clearly define the tourist products and to establish, in detail, the markets on which they are to enter [66].

If the participants can enhance the strategic marketing of dental clinics and tourism agencies from Romania instead of relying on traditional advertising channels and social media [50], dental tourism - part of health tourism - could greatly contribute to the country's image and support the extension of the seasonality [50]. At its turn, sustainable healthcare tourism - which is defined by the World Tourism Organization as being that tourism whose management ensures the economic, social, and aesthetic needs, while preserving the cultural integrity, biological diversity, and well-being of the local communities [72] - may generate opportunities for local economic development and job growth; stimulating investments; creation and development of local infrastructure; establishing intercultural links; substantial in come from the capitalization of the natural and cultural resources [73]. In the same time, the WHO focuses on providing health facilities with quality to everyone under the Sustainable Development Goals 2030 [18].

Therefore, it can be stated that sustainable development is also achieved through health tourism, especially since tourism is based on a direct link between consumers (the tourists) and the industry, the environment, and the local communities [73].

Author Contributions: Conceptualizations, F.D.O., M.R.G., A.-F.S. and M.K. (Mihaela Kardos); Methodology, F.D.O., M.R.G., A.-F.S. and M.K. (Marta Kiss); Validation, F.D.O., M.R.G. and M.K. (Mihaela Kardos); Investigations, M.K. (Marta Kiss), R.C.M.; Writing-Original Draft preparation, F.D.O., M.R.G., A.-F.S. and M.K. (Mihaela Kardos); Writing-Review and Editing, F.D.O., M.R.G., A.-F.S. and M.K. (Mihaela Kardos); Supervision, F.D.O., M.R.G., A.-F.S. and M.K. (Mihaela Kardos). All authors have read and agreed to the published version of the manuscript.

Funding: This research was funded by the "George Emil Palade" University of Medicine, Pharmacy, Sciences, and Technology of Târgu Mureș, contract research number 292/3.

Conflicts of Interest: The authors declare no conflict of interest.

\section{References}

1. Barrowman, R.A.; Grubor, D.; Chandu, A. Dental implant tourism. Aust. Dent. J. 2010, 55, 441-445. [CrossRef] [PubMed]

2. Deloitte. Medical Tourism-Consumer in Search of Value; Deloitte Center of Health Solutions: Washington, DC, USA, 2008.

3. Badulescu, D.; Badulescu, A. Medical tourism: Between entrepreneurship opportunities and bioethics boundaries: Narrative review article. Iran. J. Public Health 2014, 43, 406-415. [PubMed]

4. OECD. Health at a Glance 2011. In OECD Indicators; OECD Publishing: Paris, France, 2011.

5. Gabor, M.R.; Oltean, F.D. Babymoon tourism between emotional well-being service for medical tourism and niche tourism. Development and awareness on Romanian educated women. Tour. Manag. 2019, 70, 170-175. [CrossRef]

6. Perkumienė, D.; Vienažindienė, M.; Švagždienė, B. Cooperation Perspectives in Sustainable Medical Tourism: The Case of Lithuania. Sustainability 2019, 11, 3584. [CrossRef]

7. Turner, L. Cross-border dental care: “dental tourism" and patient mobility. Brit. Dent. J. 2008, $204,553-554$. [CrossRef]

8. Bookman, M.Z.; Bookman, K.R. Medical Tourism in Developing Countries; Palgrave Macmillan: Gordonsville, VA, USA, 2007.

9. Enache, E.; Gabor, M.R.; Morozan, C. Considerations about dental tourism development and its specific marketing in Romania. Strategii manageriale 2013, 22, 420-426. 
10. Hall, M. Health and medical tourism: A kill or cure for global public health? Tourism. Rev. 2011, 66, 4-15. [CrossRef]

11. Binoy, T.A.; Monisha, A. Dental tourism development in India: An empirical study. ATNA J. Tour. Stud. 2011, 6, 1-10.

12. Gupta, M.; Mishra, P.; Srivastava, R.; Jyoti, B. Holistic oral health care in India: A corporate perspective. J. Indian Acad. Oral Med. Radiol. 2016, 27, 237-240. [CrossRef]

13. Kovács, E.; Szócska, G.; Török, B.; Ragány, K. Why is Hungary the Main Destination in Dental Tourism? Why do Patients Choose Hungary for Dental Care? Hungarian Case Study on Dental Care and Patient Flow. 2013. Available online: http://semmelweis.hu/emk/files/2013/02/Final_case_study_web.pdf (accessed on 17 July 2018).

14. Kovács, E.; Szócska, G. "Vacation for your teeth"-dental tourists in Hungary from the perspective of Hungarian dentists. Brit. Dent. J. 2015, 215, 415-418. [CrossRef]

15. Wasik, Z. Medical Tourism on the Rise in Central and Eastern Europe. Available online: https://www.ft.com /content/24d0e36c-72eb-11e7-93ff-99f383b09ff9 (accessed on 21 May 2020).

16. Vequist, D.; Gursoy, B. Medical tourism economic report: Turkey. Econ. Facts 2009. Available online: https:// www.swisslasik.ch/fileadmin/downloads/Medical_Tourism_Economic_Report.pdf (accessed on 13 July 2018).

17. EUROSTAT. Available online: http://ec.europa.eu/eurostat/statistics-explained/index.php?title=Tourism_sta tistics/ro (accessed on 26 July 2018).

18. Hussain, A.; Asif, M.; Jameel, A.; Hwang, J.; Sahito, N.; Kanwel, S. Promoting OPD patient satisfaction through different healthcare determinants: A study of public sector hospitals. Int. J. Environ. Res. Public Health 2019, 16, 3719. [CrossRef] [PubMed]

19. Lovelock, B.; Lovelock, K.; Lyons, K. The impact of outbound medical (dental) tourism on the generating region: New Zealand dental professionals' perspectives. Tour. Manag. 2018, 67, 399-410. [CrossRef]

20. Asai, R.G.; Jones, K.D. Am I obligated to treat a patient whose need for emergency care stems from dental tourism? J. Am. Dent. Assoc. 2007, 138, 1018-1019. [CrossRef]

21. Conti, A.; Delbon, P.; Laffranchi, L.; Paganelli, C. What about the dentist-patient relationship in dental tourism? J. Med. Ethics 2014, 40, 209-210. [CrossRef]

22. Hanefeld, J.; Smith, R.; Horsfall, D.; Lunt, N. What do we know about medical tourism? A review of the literature with discussion of its implications for the UK National Health Service as an example of a public health care system. J. Travel Med. 2014, 21, 410-417.

23. Sava, C. Development of dental tourism in Timisoara, Romania. Int. MultiddscipScienConf. Soc. Sci. Arts 2014, 4, 183-188.

24. Ellis, A. Exposing the Risk of Dental Tourism. Dental Product Report. 2014. Available online: http: //www.dentalproductsreport.com/dental/article/exposing-risks-dental-tourism (accessed on 18 July 2018).

25. Conti, A.; Delbon, P.; Laffranchi, L.; Paganelli, C. Consent in dentristry: Ethical and deontological issues. J. Med. Ethics 2013, 39, 59-61. [CrossRef]

26. Jameel, A.; Asif, M.; Hussain, A.; Hwang, J.; Bukhari, M.H.; Mubeen, S.; Kim, I. Improving patient behavioral consent through different service quality dimensions: Assessing the mediating role of patient satisfaction. Int. J. Environ. Res. Public Health 2019, 16, 4736. [CrossRef]

27. Asif, M.; Jameel, A.; Sahito, N.; Hwang, J.; Hussain, A.; Manzoor, F. Can leadership enhance patient satisfaction? Assessing the role of administrative and medical quality. Int. J. Environ. Res. Public Health 2019, 16, 3212. [CrossRef]

28. Asif, M.; Jameel, A.; Hussain, A.; Hwang, J.; Sahito, N. Linking transformational leadership with nurse-assessed adverse patient outcomes and the quality of care: Assessing the role of job satisfaction and structural empowerment. Int. J. Environ. Res. Public Health 2019, 16, 2381. [CrossRef] [PubMed]

29. Deasy, R.; Kim, J.-Y.; Hong, S.-A. A comparative study of knowledge, attitude, and experience towards dental tourism between Indonesian and Korean people. J. Converg. 2014, 12, 299-308. [CrossRef]

30. Rosenmőller, M.; McKee, M.; Baetan, R. Patient Mobility in the European Union; World Health Organization: Copenhagen, Denmark, 2006.

31. Kesar, O.; Mikulic, J. Medical tourist satisfaction and dissatisfaction with dental care services: An exploratory case study. TOSEE Conf. Proc. 2017, 4, 243-258. 
32. Jaapar, M.; Musa, G.; Moghavvemi, S.; Saub, R. Dental tourism: Examining tourist profiles, motivation and satisfaction. Tour. Manag. 2017, 61, 538-552. [CrossRef]

33. Leggat, P. Dental health, "dental tourism" and travelers. Travel Med. Infect. Dis. 2009, 7, 123-124. [CrossRef]

34. Onesimo, C.V.; Jorge, C.M.M.; Ario, R.E.G. Dental tourism: Key factors that influence the selection of a dental clinic in a border region. Int. J. Advan. Res. 2017, 5, 2713-2721.

35. Ilieva, P.; Vachrlonová, D.; Christensen, L.G. Dental Tourism in Czech Republic and Bulgaria: A Potential for Danish Market [Master Thesis]. Aalborg University, 2009. Available online: http://vbn.aau.dk./ws/files/18917 574/Dental_tourism_project.pdf (accessed on 1 June 2016).

36. Stanciu, A.C.; Condrea, E.; Constandache, M. Aspects regarding the Development of the dental tourism in Romania. SEA Pract. App. Sci. 2014, 2, 588-597.

37. Gheorghe, R.; Zúrcher, A.; Filippi, A. Dental tourism from Switzerland to Germany. Swiss Dent. J. SSO 2017, 127, 618-633.

38. Nexhipi, O. Medical tourism management challenge-the case study of dental tourism in Albania. Eur. J. Stud. 2018, 10, 80-86.

39. Cohen, L.K.; Rogers, P.G. Dental tourism: An opportunity for public health. Comp. Cont. Educ. Dent. 2012, 33, 92-93.

40. Thapasum, A.; Mohammed, F. Dental tourism-global competition in health care. Med. Equip. Autom. 2012, 5, 26-28.

41. Riordáin, R.N.; McMcreary, C. Dental patients' use of the internet. Brit. Dent. J. 2009, 207, 583-586. [CrossRef] [PubMed]

42. Kamath, K.; Hugar, S.; Kumar, V.; Gokhale, N.; Uppin, C.; Hugar, S.S. The business and pleasure of teeth: Dental tourism. Int. J. Contem. Dent. Med. Rev. 2015, 2015, 1-4.

43. Adams, K.; Snyder, J.; Crooks, V.A. The Perfect Storm: What's Pushing Canadians Abroad for Dental Care? J. Can. Dent. Assoc. 2017, 83, 1-6.

44. Popescu, A. Considerations on the development of medical tourism at world level and in Romania. Sci. Pap. Ser. Manag. Econ. Eng. Agric. Rural Dev. 2015, 15, 241-252.

45. Main, I. Medical travels of Polish female migrants in Europe. Sociol.Cas. Czech Sociol. Rev. 2014, 50, 897-918. [CrossRef]

46. Turner, L.G. Quality in health care and globalization of health services: Accreditation and regulatory oversight of MT companies. Int. J. Qual. Health Care 2011, 23, 1-7. [CrossRef]

47. Gabor, M.R.; Oltean, F.D. Produse inovative În turismul național și international (Innovative Products in National and International Tourism); C.H. Beck: Bucharest, Romania, 2015.

48. Zoltan, J.; Maggi, R. What is Tourism in Dental Tourism? Available online: https://ssl.lu.usi.ch/entityws/All egati/pdf_pub5354.pdf (accessed on 21 May 2020).

49. Patients Beyond Borders. Medical Tourism-Statistics and Facts. 2010. Available online: http://www.patients beyondborders.com/medical-tourism-statistics-facts (accessed on 10 July 2018).

50. Jurišić, E.; Radović, T.C. Dental tourism-An opportunity for Croatian tourism. In Interdisciplinary Management Research XII; Barković, D., Runzheimer, B., Eds.; Josip JurajStrossmayer University of Osijek: Opatija, Croatia, 2017; pp. 297-311.

51. RNCOS. Dental Tourism on Set s a New Phase of the Romanian Dental Market. 2010. Available online: http://www.rncos.com/Press_Releases/Dental-TourismOnsets-a-New-Phase-of-the-Roman ian-Dental-Market.htm (accessed on 15 July 2018).

52. RNCOS. Romania Dental Market Analysis. 2010. Available online: http://www.rncos.com/Report/IM276.htm (accessed on 15 July 2018).

53. World Health Organization. Available online: http://www.who.int/gho/health_workforce/dentistry_density /en/ (accessed on 6 August 2018).

54. Herrera, M.R.G.; Sasidharan, V.; Hernández, J.A.; Herrera, L.D.A. Quality and Sustainability of Tourism Development in Copper Canyon, Mexico: Perceptions of Community Stakeholders and Visitors. Tour. Manag. Perspect. 2018, 27, 91-103. [CrossRef]

55. Reva Health. Available online: http://www.revahealth.com (accessed on 4 March 2014). 
56. European Travel Commission. Europe Tourism 2016-Trends \& Prospects. Quarterly Report; European Travel Commission: Brussels, Belgium, 2016; Available online: http://www.etc-corporate.org/reports/european-tou rism-2016-trends-and-prospects-(q4-2016) (accessed on 1 June 2014).

57. European Travel Commission Lifestyle Trends \& Tourism. How Changing Consumer Behavior Impacts Travel to Europe. 2016. Available online: http://www.etc-corporate.org/reports/lifestyle-trends-and-tourism (accessed on 1 June 2017).

58. ACORN. Developing a Niche Tourism Market Database for the Caribbean-20 Niche Market Profile. 2008. Available online: http://www.onecaribbean.org/wp-content/uploads/NicheMarketsDatabase.pdf (accessed on 28 May 2017).

59. Adams, K.; Snyder, J.; Crooks, V.A.; Berry, N.S. "Stay cool, sell stuff cheap, and smile": Examining how reputational management of dental tourism reinforces structural oppression in Los Algodones, Mexico. Soc. Sci. Med. 2017, 190, 157-164. [CrossRef]

60. Feltracco, P.; Maria Gaudio, R.; Barbieri, S.; Tiano, L.; Iacobone, M.; Viel, G.; Tonetti, T.; Galligioni, H.; Bortolato, A.; Ori, C.; et al. The perils of dental vacation: Possible anesthetic and medicolegal consequences. Med. Sci. Law 2013, 53, 19-23. [CrossRef]

61. Dental Tourism Abroad. Available online: http://www.dentaltourismabroad.co.uk/ (accessed on 28 May 2017).

62. Dhama, K.; Patthi, B.; Singla, A.; Gupta, R.; Niraj, L.K.; Ali, I.; Kumar, J.K.; Prasad, M. Global tourist guide to oral care-A systematic review. J. Clin. Diag. Res. 2016, 10, ZE01-ZE04. [CrossRef] [PubMed]

63. Reddy, V.K. Dental tourism-A boon to Indian practitioners. Res. Rev. J. Dent. Sci. 2016, 4, 101-103.

64. Hussain, A.; Asif, M.; Jameel, A.; Hwang, J. Measuring OPD patient satisfaction with different service delivery aspects at public hospitals in Pakistan. Int. J. Environ. Res. Public Health 2019, 16, 2340. [CrossRef] [PubMed]

65. Hussain, A.; Sial, M.S.; Usman, S.M.; Hwang, J.; Jiang, Y.; Shafiq, A. What factors affect patient satisfaction in public sector hospitals: Evidence from an emerging economy. Int. J. Environ. Res. Public Health 2019, 16, 994. [CrossRef]

66. Stăncioiu, A.F.; Botoş, A.; Orzan, M.; Pârgaru, I.; Arsene, O. Comunicare integrate de marketing în turism-o analiză. Studiu de caz: Muntenia şi Oltenia. Economie teoretică şi aplicată 2013, 20, 4-30.

67. Fink, R. Health Tourism in the EU: Facts and Figures. 2018. Available online: https://pro.regiondo.com/healt h-tourism-eu/ (accessed on 23 April 2020).

68. Commission Brundtland. Our Common Future Report; Oxford University Press: Oxford, UK, 1987.

69. Constantin, F.; Kavoura, A. Multilingual Online Communications in Corporate Websites: Cases of Romanian Dental Practices and Their Application to Health Tourism. In Springer Proceedings in Business and Economics; Springer: Athens, Greece, 2015; pp. 185-196.

70. Balázs, P. Dentists' workforce and cross-national migration. Fogorvosiszemle 2012, 105, 1-9.

71. Danial, Z.; Abbaspour, A.; Rahimina, H. Training for MT in Iran. Int. J. Travel Med. Glob. Health 2017, 5, 77-83. [CrossRef]

72. World Tourism Organization, 1996-Reports. Available online: https://www.unwto.org/ (accessed on 21 May 2020).

73. Patrichi, I. Turism durabil-o Nouă perspectivă; Prouniversitaria Publishing House: Bucharest, Romania, 2012.

(C) 2020 by the authors. Licensee MDPI, Basel, Switzerland. This article is an open access article distributed under the terms and conditions of the Creative Commons Attribution (CC BY) license (http://creativecommons.org/licenses/by/4.0/). 